\title{
MEASURES FOR THE BETTER MANAGEMENT OF AWQAF
}

\author{
Syed Khalid Rashid*
}

\begin{abstract}
This article identifies six of such problematic issues which are globally confronting awqaf and hampering their utilization for the community's betterment. These issues are: (1) An urgent need of conducting a survey of awqaf to determine their number, valuation, income, object, expenditure etc for devising an effective administrative policy. (2) Democratisation of waqf administration to allow muslim public participation to dilute the present state control. (3) To revisit the status of family awqaf and its pathetic condition today. (4) To search for alternatives to the colossal waste of waqf income on litigation. (5) The need to replace litigation with administrative action for the recovery of encroached properties. (6) To find ways of developing millions of dormant waqf properties, as this is the key to the treasure trove that remains untapped.
\end{abstract}

Professor of Law, International Islamic University, Malaysia. This paper was prepared by the author during his stay with IRTI, IDB, Jeddah-Saudi Arabia during May-June 2011. E-mail: skrashid@hotmail.com 
Keywords: survey, encroachment, democratization, development, family awqaf.

\title{
LANGKAH-LANGKAH KE ARAH PENGURUSAN WAKAF YANG LEBIH BAIK
}

\begin{abstract}
ABSTRAK
Makalah ini mengenalpasti enam isu sejagat yang mendepani wakaf dan menghalang pemanfaatannya untuk pembaikan masyarakat. Isu-isu ini adalah (1) satu keperluan yang perlu disegerakan untuk menjalankan satu tinjauan terhadap wakaf untuk menentukan bilangan, penilaian, pendapatan, perbelanjaan wakaf dan lain-lain untuk membuat satu polisi pentadbiran yang berkesan, (2) pendemokrasian pentadbiran wakaf untuk membenarkan penyertaan orang awam Muslim untuk mencairkan kawalan negara sekarang; (3) untuk melawat semula status wakaf keluarga dan keadaannya yang menyedihkan pada hari ini; (4) untuk mencari alternatif kepada pembaziran pendapatan wakaf yang amat banyak pada litigasi; (5) keperluan untuk menggantikan litigasi dengan tindakan pentadbiran bagi mendapatkan kembali harta yang dicerobohi; (6) untuk mencari jalan untuk membangunkan jutaan harta wakaf yang terpendam, kerana ini adalah kunci kepada harta karun yang masih belum dimanfaatkan.
\end{abstract}

Kata kunci: tinjauan, cerobohan, pendemokrasian, pembangunan, wakaf keluarga. 


\section{PRELIMINARY REMARKS}

When Umar Bin Khattab asked the Prophet (S.A.W) how could he make the pious use of his land in Khyber, the Prophet (S.A.W) replied: Tie up (habs) the corpus (asl) and give away the fruits (thamarat). This reply suddenly changed the whole concept of charity by weaning it away from consumption of corpus as well as usufruct to perpetuation of corpus and appropriation of usufruct alone. It was something unknown to the world up to that time.

Its simplicity and perpetuity made waqf very popular. For the rest of 1300 years it remained the most popular expression of Muslim philanthropy. Millions of awqaf were created for every conceivable object. But with colonialism came misery as thousands of awqaf were abolished or put to other uses and governed by alien rules.

The post-colonial new nations were too busy with bigger issues of nation-building and had little time to attend to waqf management problems. Subsequently, some attention was given, but many issues remain unresolved.

This paper identifies certain problematic issues now confronting awqaf and ventures to suggest some remedial measures. Awqaf worth billions of dollars, possessing enormous potential for the socio-economic regeneration of the Ummah are waiting to be utilised and managed more effectively.

Issues raised in this paper do not cover diverse matters but present a narration of inter-connected matters aimed at reviving waqf and improving waqf management. Legal jargons are avoided to the best possible extent. Similarly, suggestions are broad-based to make them capable of being adapted in any country with minimal changes.

This paper briefly discusses the following six issues:

1. Survey of waqf properties: Its importance and suggested legal structure.

2. Democratisation of waqf administration.

3. 'Revival of family awqaf'.

4. How to avoid wastage of waqf funds on litigation?

5. How to recover encroached waqf properties without going to court of law?

6. Development of waqf properties: A case of little utilized potential. 


\section{SURVEY OF AWQAF: IMPORTANCE AND STRUCTURE}

\section{Importance of Survey}

A comprehensive survey of waqf properties is a pre-requisite for effective waqf management. How could a waqf administrator effectively manage awqaf under his charge without knowing their exact number, nature, value, income, objects, administrative structure and other details. Only on the basis of information supplied by a comprehensive survey that a viable waqf land development policy may be formulated. Emphasising the importance of survey of awqaf, Sir Abdur Rahim, the well known author of a book on Islamic Jurisprudence and a Judge of the Madras High Court in India, said in 1918:

"The first thing necessary is that the facts regarding them (awqaf) should be authoritatively ascertained...when such investigation has been completed, the authorities will be in a position to devise appropriate legislative and executive measures to meet the situation." ${ }^{1}$

Details which only surveys could provide may become handy in policy formulations regarding the selection of such awqaf whose objects are generally charitable as distinct from those which are reserved for specific objects and any deviation that may create legal problems. It is therefore advisable to give priority to the development of those awqaf, the income from which may be legally utilized for any socio-economic uplift programme. This, however, does not mean that other awqaf are not worthy of being developed. Their turn will come, but only afterwards, as financing is very limited.

Sometimes registration of awqaf is confused with survey. These are two different things. Registration is based on the information provided by the mutawallis (managers) to officers who have no authority to enter into an enquiry as to the correctness or otherwise of the information furnished. Registration is therefore a mechanical thing where details

Sir Abdur Rahim's foreword to P.R.Ganpathi Iyer's Hindu and Muhammadan Endowments (Madras,1918). 
supplied are recorded without any question being asked. On the other hand, survey starts with questioning, enquiry and investigation. Nothing is accepted at its face value. The fact that the officer conducting survey is endowed with judicial powers, makes his enquiry and findings much more reliable, unlike registration.

\section{No Survey Conducted}

Apart from India, a proper survey of waqf properties has yet to be conducted in every country of South Asia (Pakistan, Bangladesh, Sri Lanka, Maldives and Nepal); South-East Asia (Malaysia, Indonesia, Thailand, Singapore and Brunei), West Asia and East, West, North and South Africa, not to mention Western countries where millions of Muslims reside where there must be a large number of awqaf.

Presently, reliance is placed on land records, registration records or voluntary declarations by waqifs (settlors) or mutawallis (managers), or the self-evident nature of the property, like a mosque or graveyard, etc. Naturally, figures collected through such sources cannot be accurate, and represent mere estimations.

\section{Survey May Reveal Concealed Waqf Properties}

As an illustration, let us take India. In the early 1960's, the number of awqaf officially given by the Minister-in-charge of awqaf was $100,000 .^{2}$ However, a 2003 survey revealed the identity of another 200,000 more awqaf, hiking the total figure to $332,000 .{ }^{3}$ As second survey is still not complete, the total is expected to exceed 375,000 , and may even touch 400,000 .

If we look at the figures of only two Indian States, Andhra Pradesh and Rajasthan during early 1960's, these are very revealing. In Andhra Pradesh for example, there were only 3,300 registered and 12,000

$2 \quad$ Syed Khalid Rashid, Waqf Administration in India: A Socio-Legal Study, (Vikas Publishers, New Delhi, 1978), at 74.

3 Syed Khalid Rashid, "Current Problems Facing Awqaf in India: Possible Solutions,” Awqaf(Kuwait), at 12. 
un-registered waqf properties, ${ }^{4}$ that is a total of 15,300 . But within a few years after survey started, the total number of awqaf shot to 35,709.

In Alwar district of Rajasthan during 1960's only 73 waqf properties were known to exist. But soon after the survey started this figure jumped to $1965 .^{5}$

This must be the case in other States too, otherwise the total number would not have jumped from 100,000 to 332,000. In all probability, a similar situation could exist in other countries too. The prospect of unearthing thousands of 'underground' awaqf is indeed exciting and worth undertaking. Developmental potential of these properties must be very high, because only the identity of such properties is generally concealed.

\section{Statutory Provisions Are a Must for Survey}

Law attaches great importance to disputes involving ownership of land. This is why such disputes are adjudicated in civil courts. But a serious problem arises out of the fact that civil litigation is extremely slow, costly and cumbersome. So if during the survey of awqaf, a dispute arises involving ownership of an alleged waqf property, the matter if referred to a civil court should be considered as taking a very long period of time for its resolution. The notorious Babri Mosque case in India was filed in 1948 and only in 2010 that the High Court gave its judgement. Now an appeal against this judgement is pending in the Supreme Court and no one knows when the judgement may come.

So waqf disputes arising during survey should not be referred to civil courts. But who then will settle them. Anyone who as an alternative is chosen to discharge this function must be endowed with equivalent powers as a civil court but not bound to follow the same lengthy procedure. As only a statute may do this, it becomes a necessity to have statutory provisions. Details of these judicial powers should be clearly stated, so also the competence of the person exercising these powers. Whether or not an appeal may be made against the decisions of this

\footnotetext{
$4 \quad$ Mimeographed Report of Andhra Pradesh Waqf Survey Commissioner, 1964-65 (Personal Collection).

5 Report of Waqf Survey Commissioner, Rajasthan 1964, Jaipur Rajasthan (Mimeographed copy), Personal collection.
} 
alternative judicial authority would be a matter of great importance and need to be specified in the statute along with other things.

\section{Only Someone Vested With Judicial Powers Could Effectively Conduct Survey}

To sit in judgement over such a loaded question whether a particular property is waqf involves judicial determination of the question of its ownership. It is to be remembered that once a property is declared as waqf, its ownership vests in Allah and anyone who calls himself as its owner will be permanently debarred from calling himself as such. To make such a declaration is a delicate exercise and can be only undertaken by someone who is vested with judicial powers.

Such an officer could only be appointed by the Government, through official notification. Thus a Waqf Survey Officer (WSO) and as many of his Deputies or Assistants, with supporting staff, are to be appointed. Provisions about such appointments and related matters shall be there in a statute and rules made thereunder. In countries following federal system, these provisions may be contained in the federal waqf law and subordinate rules, but in non-federal countries like Pakistan plurality of waqf enactments will demand survey provisions to be inserted in all of them. In still other countries there may be some other legal situation which needs to be compiled with.

The Waqf Survey Officer (WSO) shall have the same powers as that of a Civil Court to empower him to make judicial determination. Among other things, he should be empowered to deal with matters like:

i) Disputed ownership of an alleged waqf property;

ii) Nature of a waqf sunni or shia, public or private, etc;

iii) Compelling a person to appear as a witness;

iv) To requisition a record from a court or office;

v) To appoint commissions for recording evidence of a person who is unable to come personally;

vi) To order 'discovery' of any document or record;

vii) To conduct personal inspection of a disputed site;

viii) To issue restraining orders;

ix) To hold a person in contempt of court for defying any of his orders; 
x) To appoint a Receiver of a waqf property which is under investigation;

xi) To issue interlocutory injunctions and orders and

xii) To deal with such other matters which are specified in the Rules made under the Act.

\section{What Types of Enquiries Are to be Made?}

A thing which is necessary to be spelled out first in a statute dealing with survey is a comprehensive definition of 'Waqf', as in most cases this is what lies at the bottom of a dispute. Moreover, in law, definitions are given prime importance for obvious reasons. Where there are several waqf enactments in a country, like Pakistan and Malaysia, the definition should be uniform to avoid confusion. The following may be taken as a working definition of waqf.

"Waqf is a perpetual dedication of a property for any object recognised by the Islamic law as religious, pious and charitable and includes:

i) an endowment of title to some property from which any benefit, interest or profit may be derived;

ii) an endowment of any interest in or profit from some property;

iii) a 'waqf by user,' and such waqf shall not cease to be a waqf by reason only of the user having ceased, irrespective of the period of such cesser;

iv) grants or nazar customarily recognised as religious and charitable;

v) a family waqf (waqf al alaulad); and

vi) waqf al nuqud (cash waqf).

The WSO should make very detailed enquiries about a property alleged or known to be waqf. The scope of his enquiries should be spelled out, as much as possible, in the statute itself or in the rules made there under. Details may differ from country to country, but broadly the scope of the enquiries to be made by WSO should consist of investigations into:

i) the income and expenditure, verified by spot visits;

ii) illegal occupation of a waqf property, verified by local witnesses, spot inspection, etc; 
iii) the gross income as compared with net income;

iv) payment of taxes, land revenue, levies, etc;

v) expenditure on litigation and who was defendant, mutawalli personally or the waqf;

vi) the object of waqf and extent of its fulfillment;

vii) matters considered relevant by the WSO.

Since all the details of the enquiries to be made by the WSO cannot possibly be contained in the Act, some may be contained in the Rules framed under the Act. No comprehensive listing of these details is possible because these may differ from one country to another. But a good sampling of these detailed enquiries may be as follows:

i) Background of the waqf and the waqif;

ii) Date of creation, if known;

iii) Details of the object as mentioned in the deed, if any, or on the basis of evidence;

iv) Detailed description of waqf property, its location and distance from the market, main road and railway station, its strategic location, etc;

v) Encumbrances or changes if any on the waqf property;

vi) The current mode of administration: whether devised by the waqif, mutawalli or court or custom and usage;

vii) Details about the mutawalli, his appointment, conditions, if any, attaching to his office, etc.

Sometimes, the field-staff conducting surveys might not be knowledgeable enough and need to be instructed and educated as how to determine the nature of a property as waqf. For this, the WSO may issue the following instructions, (given here only as sampling):

i) The presence of some graves on a plot of land whose owner raised no objection against such public burials even when he knew about it, makes the plot waqf as a public graveyard;

ii) Trees standing on a waqf land and income derived out of these shall form part of the income of waqf;

iii) The ruins of a waqf building or any structure in whatever dilapidated condition should be counted as waqf;

iv) Income from some shops outside a waqf building but attached 
to it, or income derived from the water pumped out of a well in a mosque should be treated as income belonging to the waqf;

v) Income of a waqf includes;

a) Produce of the garden which is on a waqf land

b) Any offerings made on special occasions

c) Nazar presented at the dargahs (tombs of famous Muslim saints);

vi) Books in the library of a mosque, dargah or any other waqf property shall be presumed to be waqf unless proved otherwise.

\section{Whether Only 'Existing' Awqaf Should Be Surveyed or The Survey Also Extended to'Extinct' Awqaf}

Here by 'extinct' is meant such a waqf which is alleged to have lost its waqf character because of encroachment, converting it into the 'personal' property of the encroacher, particularly when he is a non-Muslim, and objects to the WSO's competence to make enquiry into his 'personal' property.

This plea of the encroacher was upheld by the Rajasthan High Court in the well-known case of Radha Krishna vs State of Rajasthan, AIR 1967 Raj1. The court held that WSO had no authority to decide about such a waqf property which became 'extinct' due to encroachment. WSO was to survey only 'existing' waqf properties.

In this case, a waqf building was first mortgaged by its caretaker and then sold to the same person who held it on mortgage. The WSO found the building as waqf and the person who sold it was not its 'owner.' The WSO therefore included this property in the 'Waqf list.'

The 'owner' of the building challenged the competence of the WSO to include his property in the Waqf list. He requested the WSO to refer the matter to the Civil Court. This request was rejected by the WSO who pointed out his own status as a Civil Court and hence his competence to do whatever he did.

The 'owner' then filed a writ petition in the Rajasthan High Court challenging the action of WSO. The court upheld the challenge and observed:

"He (WSO) has obviously no jurisdiction either to decide any question relating to the title of the petitioner (the 
owner) or to eject him without going to a competent civil court. (The WSO is invested with the powers of a civil court) to enable him to make proper survey of existing waqf properties and not of those which have already become extinct. If a person is a non-Muslim in possession of a certain property, his right title and interest cannot be put in jeopardy simply because that property is included in the list published under (law).”

This verdict of the court is obviously wrong, because how could an unlawful sale of a waqf property make it 'extinct.' A validly created waqf remains valid in perpetuity, notwithstanding its unlawful sale. Hence WSO was right in declaring the building as waqf and including it in the waqf list. This list may be challenged in a Civil Court, but this fact does not affect the right of WSO to include this property which he found as waqf, to be included in the waqf List. The Waqf (Amendment) Act 1969 has corrected this defect and WSO may include now any property in the waqf List.

This mischief was caused by the use of the word 'existing' in section 4(1) of the Waqf Act 1954 and even now in the Waqf Act 1995 of India. This word creates an impression that there are 'extinct' awqaf also. Thus, any law enacted for the purpose of survey of awqaf should avoid using the word 'existing' along with waqf. Mere use of the word 'waqf' should be taken as enough; no need to use the prefix 'existing.'

The issue raised by the High Court that a non-Muslim 'encroacher' is beyond the reach of WSO is simply not correct. A waqf property illegally held by a Muslim or non-Muslim will remain an encroached property. To assume that law exempts a non-Muslim from being challenged by the WSO simply because he is holding an 'extinct' waqf property is untenable. Religion of the encroacher is irrelevant.

\section{Rights of a Person Who Was Not Made a Party to the Survey Proceedings}

The inclusion in the Waqf List of a property in which a person has some interest but to whom no 'notice' was given by the WSO during survey proceedings, can challenge such inclusion even after the expiry of one year which otherwise makes the Waqf List final. The Rajasthan High 
Court in its judgement in the case of Radha Krishna $v$ State of Rajasthan, AIR 1967 Raj.1 emphasized the importance of notice to such persons. Madras High Court supports this view (see, case no W.P 1142/ 66 decided on 7.4.1969). It was held that publication of Waqf List was hardly a substitute for notice because nobody was expected to look into the Government Gazette everyday at the risk of losing his property rights.

\section{Waqf By User Is Unaffected By Cesser}

In cases where there is no direct evidence of dedication of a property as waqf, reliance is to be placed on its 'long user' to infer its waqf nature. Since a waqf by user is based on presumption, which in its nature is rebuttable, hence at the time of inclusion of a property in the Waqf List, it may be challenged and its waqf nature may be disproved. However once it is declared as waqf on being proven to be so, there is no presumption attaching with this property anymore.

An example of waqf by user is a room or covered area built adjacent to a mosque not necessarily to accommodate additional worshippers, but who started praying there without any objection being raised by the owner and this continues for a long time, making the room or covered area to become waqf by user. The user must be of an unequivocal nature which may lead only to an inference of dedication. What needs to be established is the conduct of the owner of property in not raising any objection, even while knowing that his property is being used in a particular manner.

Once the Punjab High Court in India took the wrong view that a waqf by user may cease to be waqf by virtue of long cesser of use. ${ }^{6}$ However, the Supreme Court corrected this wrong by holding that a waqf by user does not come to an end whether it is used or not. ${ }^{7}$ Because of these two cases, the definition of waqf contained in Section 3(r)(i) clearly provides:

(Waqf includes) 'a waqf by user, but such waqf shall not cease to be a waqf by reason only of the user having ceased, irrespective of the period of such cesser.'

\footnotetext{
6 Panchayat Deh v. Punjab Waqf Board, AIR 1969.

$7 \quad$ Punjab 344 Mohd.S.Labbai v. Mohd. Hanifa, AIR 1979 SC 1569.
} 


\section{What Should be The Forum to Challenge Waqf List?}

An important legal question which arises after the completion of survey and inclusion of a property as waqf in the Waqf List, is whether such an inclusion may be challenged. If yes, where? To allow this matter to be brought to a Civil Court may open the Pandora box of costly and prolonged legal battle.

In countries having Shariah Courts, which are relatively faster and economic, the matter may be brought to them. However, where the plaintiff is a non-Muslim and not covered by the Shariah Court's jurisdiction, he naturally will have to be allowed to go to the Civil Court, or preferably to some other forum specially created for this purpose, and which is designed to avoid the negative elements of civil litigation.

An Endowment Tribunal may be the answer. A Tribunal is a judicial body but, unlike a court of law, is not obliged to follow the same procedural law and rules of evidence which cause delay and escalate cost. Tribunals are therefore fast and inexpensive.

Such Tribunals may be constituted by the Government by inserting provisions in the existing Waqf Act, if there is one, or in a specially enacted law. These Tribunals are for the adjudication of any dispute relating to a waqf property or any question arising during the survey. Any person aggrieved by an order made by Waqf Survey Officer (WSO) may file an application, within the time prescribed for this purpose, for the determination of any dispute or question regarding a waqf property.

The Tribunals shall be deemed to be a Civil Court with the same powers. It shall be presided by a Muslim member of the Judiciary holding the rank of a senior judge either of District or High Court level.

The Tribunals shall follow the brief procedure as prescribed over for it by the Government in consultation with the judiciary. Its decision shall be binding and final, and shall have the force of a judicial decree.

No appeal shall lie against any decision or order of Tribunal. However, wherever it is regarded advisable, the High Court may be allowed to review the decision of the Tribunal for the purpose of satisfying itself as to the correctness and legality of the decision.

The Tribunal shall normally take not more than 90 days in determining the merits of a case.

No suit or other legal proceeding shall lie in any civil court in respect of any dispute, question or other matter relating to a waqf which is required to be adjudicated by the Tribunal. 


\section{Waqf List: Whether Changes Could be Made?}

After the completion of survey, the WSO should submit the Waqf list to the Government for publication in the official Gazette.

The question whether the Government or any waqf administration body that may exist in a country, may effect changes in the Waqf List is very important. None should be allowed to do so, because Waqf list represents the final outcome of a field work and consists of factual information collected after judicial scrutiny. Neither the Government nor anyone might have such solid proof that might override WSO's findings. However, in exceptional cases WSO may be recalled for joint deliberations and consultations to agree on any change.

Submission of Waqf List is usually at the end of survey work. However, periodic submission of partial reports may be allowed if it suits WSO's convenience. It may even be better for the officers examining the report as they will get more time to do this work.

\section{Helping Hand of NGO's, Public and Muslim Organisations}

The survey of waqf should be given wide publicity through newspapers, $\mathrm{TV}$ and radio announcements, highlighting the importance of the cooperation and assistance of the public, NGO and Muslim organizations. They may bring to the notice of WSO such information which they alone may be having. Generally they may reveal the identity of concealed waqf and facts which an outsider might never get. What the public involvement may achieve is very clear from events in Egypt, Tunisia, etc.

\section{State Must Bear the Cost of Survey}

The total cost of survey of awqaf and the publication of Waqf List must be borne by the State, as part of State obligation and a matter of public benefit. In India Section 8 of the Waqf Act 1995 requires all the mutawallis of nearly every waqf to bear the cost of survey. It is an unfortunate provision and need to be deleted. 


\section{DEMOCRATIZATION OF WAQF ADMINISTRATION}

By 'democratization' is meant Muslim public participation in waqf administration in contrast to total or predominantly State control. It is an issue of waqf administration today. Governmental control is not accepted by the people in an essentially private sector matter. Muslims want to have some say in this matter. Doing so may bring dynamism, greater vigilance and control on waqf matters. What may be the format and extent of public involvement may differ from country to country, but what is important is that it should be meaningful, not a mere window dressing exercise.

The Ottoman takeover of the direct control of waqf management changed the rule of the game. It also provided an excuse to the colonial powers to do the same. A pattern of governmental control came into being which unfortunately continues even now. Direct control on awqaf is so alluring and power addicting that it becomes difficult to give it up. It is to be realized by the Government that power-sharing is in its own interest. It may save it from many accusations and criticisms. However, it may also be not in the best interest of waqf administration that it is totally handed over either to the public or to the mutawallis. A sort of administrative power-sharing between the government, public, beneficiaries and mutawallis, may be an ideal solution.

Example may be given of the formula that exists in India under the Waqf Act 1995. Out of the 13 maximum members in the State Waqf Board, 5 are nominated by the government and 8 are elected by electoral colleges. The details are as follows:

One and not more than two members are to be elected from each of the following 4 electoral colleges consisting of:

i. Muslim members of Parliament from the State

ii. Muslim members of the State Legislature

iii. Muslim members of the Bar Council of the State, and

iv. Mutawallis of awqaf having annual income of Rs.100,000 (US\$2000.00) and above.

Two to four members to be nominated by the State Government from the following categories of persons: 
i. $\quad$ Eminent Muslim organizations

ii. Recognized Scholars in Muslim theology.

Another member to be nominated by the State Government is an officer of the same Government not below the rank of Deputy Secretary.

This power-sharing is at the State level and it is very difficult for a member to know about the happenings at the grass-root level. Muslim public involvement should be at the level of village, tahsil and district. The Village Waqf Committee shall consist of 10 members elected from a group of 10 Villages, Tahsil Waqf Committee consisting of 20 members elected among the members of the Villages Committees within a Tahsil and District Waqf Committee consisting of 30 members elected among the members of the Tahsil Committees within the district. This mode of election will be quicker, economical and peaceful. The members of all these Committees shall act on voluntary basis without being paid any allowance or remuneration. Their duty will include keeping an eye on waqf matters within their jurisdiction and informing the next higher Committee about relevant matters.

At the state level, the percentage of elected and nominated members is a matter of mutual understanding. 60:40 appears to be a good ratio between the selected and state nominated members of the State Board.

\section{FAMILY AWQAF DESERVE A BETTER DEAL}

\section{Legal Validity of Family Waqf}

In Islamic Law, the sanctity and legal validity of a family waqf is well recognized and established. It is so because this waqf finds indirect support from the Qur'an and Hadith. For example, in Surah Al-Baqarah (2) ayat 177 and 215 Allah praises those who help their "kinsfolk," "parents and near kindred.” Similar praise is reserved in Surah Al-Nahl (16) ayat 90 for those who show "Liberality to kith and kin." Similar is the attitude of the Prophet (S.A.W.). Chapter 368 of Volume 2 of Sahih Muslim consists of 11 ahadith, all of which narrate the excellence of giving to one's own family, that is, wife, husband, children, parents and other relatives. In one of the hadith, the Prophet (S.A.W.) is reported to 
have said: "the most excellent dinar is one that a person spends on his family." A large number of family awqa were created by the companions of the Prophet (S.A.W.). It is reported in Fath al-Qadir, Vol. 2, at 844 (Lucknow, 1875) on the authority of Ibn al-Humam that Abu Bakr Siddiq made waqf of his house for his children. Sa'ad bin Abi Wiqas made waqf of his house in Medina and Egypt for the benefit of his children. As mentioned in Fath al-Qadir, similar awqaf were created by Umar, Usman, Ali, Abdullah bin Zubair and Abdullah bin Umru and Arqam in whose house the Prophet (S.A.W.) resided for some time.

The popular English adage that 'charity begins at home' is an empty slogan. In English law, charity never begins at home. Because a private trust in favour of one's own children, spouse and relations, is regarded as a private trust, which is subjected to various taxes like Income Tax, Estate Duty, Wealth Tax, etc., and as compared with charitable trusts, suffers a number of disadvantages. In Islamic law, on the other hand, no distinction is maintained between various types of waqf whether religious, charitable or family of which all have same legal incidents and implications in matters of legal validity.

\section{Effect of Colonial Onslaught on Family Waqf}

After the colonization of Muslim countries, the colonial powers started transplanting Western legal concepts and rules in the Muslim countries. What survived was Muslim Personal Law dealing with personal matters, including waqf. Even though family waqf was disliked by the British colonists, yet on political considerations these awqaf were left untouched. However, what the British Crown could not do, the English judiciary did. In 1894, the Privy Council, in its notorious judgment in Abul Fata Mohameds' Case (1894) 22 I.A. 76, held that family waqf (waqf al alaulad) was void. The reasoning of the judgment was based on the English notion of charity and the concept of non-charitable trust in favour of children and other relatives.

Nearly the same reasoning which English judiciary used in invalidating family waqf became, later on, the rationale behind the abolition of such awqaf in Egypt, Syria, Libya, Tunisia and UAE. It may be argued that probably what encouraged these countries was the abolition of awqaf by Turkish Government in 1926. That however, was not aimed at awqaf alone but was part of the wholesale Westernization of Turkish laws. This 
was not the case in Egypt and other countries, which based their abolition of family awqaf on account of certain alleged defects, including that it affected national economy.

In countries, like India, Pakistan, Bangladesh, Myanmar, Malaysia, Indonesia, Sri Lanka and Singapore, so also in Kenya, South Africa, etc., though family waqf is still allowed yet these are subjected to the same disqualifications with which, under English common law, private trusts suffer.

The hostility towards family awqaf which started during the colonial rule still manifests itself in the attitude of indifference maintained in the above-mentioned countries. These awqaf are not supervised like other awqaf. Lack of supervision is a sure recipe to breed corruption and malversation, which are taking these awqaf towards a slow but sure death.

\section{Position in Malaysia}

Here, it may not be out of place to mention in passing, a peculiar restriction imposed on the creation of family waqf (called waqf khas) in Malaysia. In 10 out of 13 States and Federal Territories waqf laws in Malaysia, a waqf khas (family waqf) is regarded null and void unless the Sultan of the State, and in case of Federal Territories, the Yang di Pertuan Agong, has expressly sanctioned and validated this creation.

The requirement of seeking such permission for creating a family waqf is a restriction which finds no support either in Islamic law or Islamic history. This is not the case while creating other types of waqf which amounts to an admission of the fact that the State does not like the free creation of family awqaf in Malaysia. Probably, the Johor State's Waqf Prohibition Enactment of 1911 (which was repealed only in 1978) that imposed a blanket prohibition on the creation of family waqf, is still haunting the governments of these nine States and the Federal Territories from its grave.

With the establishment of Shariah Courts in Malaysia, waqf disputes, including disputes relating to family waqf, are to be referred to these courts and not Civil Courts as was the case earlier till 1988. The attitude of the High Court of Terengganu (in Malaysia) can be gleaned from a judgment given in 1970: 
“..... on the authority of the Privy Council's decision (in Abu Fata Mohamed's Case) we are bound to hold that the family waqf was void, notwithstanding the Mufti's ruling to the contrary. This embarrassing situation can only be set right by legislation, as has been done in India and other places."

As the family waqf created by the Royal family in this case consisted of land worth RM150 million, the State Government went ahead and passed the Waqf Validating Enactment 1972, Terengganu (No.10 of 1972). This was a local Act of a State hence legally Privy council's verdict in Abul Fata's case disallowing family waqf was still considered binding in others States in line with the doctrine of precedent of common law, whereby the Civil Courts considered themselves bound by the Privy Council's ruling against family waqf. Now, fortunately, Shariah Courts, which assumed jurisdiction on waqf since the Constitutional amendment of 1988 are not legally bound by the Privy Council's judgment, as the doctrine of judicial precedent is not recognized in Islamic law. However, the court cannot override the other statutory restriction requiring the Sultan's permission.

\section{Need for a Reexamination}

One of the justification given by those opposing family waqf is the gradual fragmentation of usufruct among ever increasing number of beneficiaries, so that with the passage of time, the quantum of each share is reduced to insignificance. Those orientalists who opposed the Islamic law of inheritance gave the same reasoning in their support. But the experience of 1400 years shows no adverse effect of this fragmentation. In case of family waqf also, those beneficiaries who may be well off may like to abdicate in favour of those who need more help. Moreover, benefit coming from a family waqf might not be the sole source of income of a beneficiary. So the inadequacy or adequacy of benefit becomes irrelevant.

It might be argued that once the creation of family waqf is freely allowed, there will be sudden jump in their number, immobilizing too much

$8 \quad$ Justice Suffian in Commissioner for Religious Affairs, Terengganu v. Tengku Mariam, (1970) IMLJ 222. 
of available land, thereby affecting national economy. ${ }^{9}$ However, this appears to be a mere apprehension. If we look at countries which never imposed any restriction on the creation of waqf, including family waqf, the number of awqaf is not very high. In India, for example, for a Muslim population of 155 million, we have just 332,000 awqaf, and majority of these are mosques and graveyards, created over nearly 800 years.

Countries which abolished family awqaf never conducted any academic research or field-study to prove the undesirability of such awqaf. If their perpetuity character was offending, it was understandable that their life-span was reduced, but then if these were totally abolished, one would like to know why. The abolition cannot be based on ijtihad, because it cannot override favorable policy declarations in the Qur'an, hadith and ijma of giving to one's kith and kin. The abolition is reflective of Western thinking on charity. West regards waqf as Dead Hand (mortmain), a handicap to the natural growth and development of a healthy economy. The approval of perpetual charitable trusts is however conveniently ignored. A case of double standards indeed.

It was once said by a modernist Muslim, criticizing family waqf, that-

"When a father provides a certain income for his children and descendants, the impulse to seek education and the initiative to improve their lot gradually decrease. Charitable aid often keep people away from industry, and lethargy breeds degeneration....it can by no means be said that the institution of waqf as a whole has been an unmixed blessing to the community.” ${ }^{10}$

The same criticism may, however, also be labelled against a charitable English trust. By guaranteeing a definite benefit coming the way of beneficiaries in a charitable trust, these beneficiaries are kept away from industry.

9 Daniel Latifi, "Law of Family Waqf: Need for Reconsideration,” in Tahir Mahmood (ed.), Islamic Law in Modern India, (Bombay, 1973), at 229-30.

$10 \quad$ Asaf Ali Asghar Fyzee, Outlines of Muhammadan Law, $3^{\text {rd }}$ ed. (Oxford University Press, 1964), at 266-67. 
In a family waqf it may only be rare to find that the benefit reserved for a beneficiary may be sufficient for all of his needs. Thus, he has to work to make a decent living. The assumption that family waqf benefits make every beneficiary affluent and thus lethargic is simply not correct.

There is a need to undertake a field study to ascertain the problems which family awaqf are facing or faced in the past, the validity of the criticisms made against them, the opinion of the Ulema and the public, to ascertain the nature of the problems, in order to search for appropriate solutions.

If perpetual tying up of property is their problem, or fragmentation of income as a result of distributing it among ever increasing number of beneficiaries, then reducing its life span to, say, 30 years may be the solution, not abolition as the waqif is mainly concerned with the welfare of his immediate descendants and relatives. During the reduced life span of such waqf, the beneficiaries will have enough time to establish themselves assisted with waqf income. Knowing the fact that the benefit coming their way is only for a limited period, they may not become addicted to any 'indecent' expectations.

This is an ad hoc suggestion, which should not be taken as an acceptance of any particular criticism against family waqf which may only be confirmed through field study.

It needs to be added by way of clarification that family awqaf should be exempted from direct taxes and should be brought under the supervision of the waqf supervisory body. Their down-graded status, under the influence of English law of trust, must be reviewed. All benefits presently enjoyed by charitable waqf should be extended to family waqf also, as in Islamic law, there is no distinction between the two status wise.

\section{HOW TO AVOID WASTAGE OF WAQF INCOME ON LITIGATION}

\section{Waqf Tribunals: A Possible Solution}

Disputes invariably arise in all human activities, including waqf administration. Generally these are adjudicated through litigation in civil courts. The number of such cases varies from country to country but it is 
generally very high, particularly in South Asian countries like India, Pakistan and Bangladesh. It is a matter of concern to find that a large amount of money is being wasted on litigation. The money could have been used for some better objects.

In countries having Shari ' $a$ h courts, there is no need to establish any alternative judicial body, as these courts are neither as costly, slow nor technical as civil courts. Therefore there is no need for any alternative body in these countries. However, if the jurisdiction of the Shari'ah Court does not extend to non-Muslims who happen to be involved in a waqf dispute, two options would be available:

i. The court which has jurisdiction over non-Muslims will adjudicate this dispute; or

ii. To establish Waqf Tribunals to adjudicate.

In India, Waqf Tribunals are empowered to try such cases that have been established under the Waqf Act $1995 .{ }^{11}$ Initially the idea of Tribunals was proposed in my doctoral thesis approved in 1971 and the importance of establishing such Tribunals. ${ }^{12}$ In Sri Lanka, provisions relating to Waqf Tribunal were inserted in the relevant waqf law through a 1982 amendment. In no other country there is a provision for such a Tribunal.

\section{Establishment and Powers of Waqf Tribunals}

Any country wishing to establish Waqf Tribunals need to legislate laws regarding their powers, jurisdiction and establishment.

\section{a) Establishment}

i. The State may establish as many Waqf Tribunals as required by notification in the official gazette.

$11 \quad$ See, section 83 of the Waqf Act, 1995.

12 Title of the PhD thesis: "A Socio-legal Study of Waqf Administration in India,” Law thesis. Aligarh Muslim University. Aligarh, which was published as Waqf Administration in India: A Socio-Legal Study (Vikas Publishing House, New Delhi, 1978). 
ii. Every Tribunal shall consist of one Judge of the status of not below the rank of a District Judge, having knowledge of waqf laws, and should be a Muslim.

\section{b) Powers}

i. The Tribunal shall be deemed to be of the status of a civil court and shall have the same powers as exercised by civil courts, while trying a case or executing a decree or order. In India, section 83(8) of the Waqf Act, 1995 does not allow Waqf Tribunal to execute their decisions, for which they need the help of the civil court. It is odd to confer on the Waqf Tribunal the status of a civil court and then to deny it the power to execute its decision.

ii. The Tribunal shall follow its own procedure and rules made for it by the government, and not the procedure followed by the civil courts.

iii. The Tribunal's decision shall be final and binding on the parties and shall have the force of a decision made by a civil court.

iv. The Tribunal shall have power to execute its decision or order.

v. No appeal shall lie against any decision or order, whether interim or otherwise, of the Tribunal.

Provided that the High Court may, on the application of the aggrieved party call and examine the records relating to the dispute, question or other matter which has been determined by the Tribunal for the purpose of satisfying itself as to the correctness, legality or propriety of such determination and may confirm, reverse or modify such determination or pass such order as it may think fit.

This provision is necessary because review power is generally exercised by the High Court, in cases of this type where no appeal is allowed. It may also be in the interest of Tribunal. The realization that its decision is liable to be reviewed by the High Court will make it more responsible and careful in its determinations. 
vi. The Tribunal shall hold its proceedings as expeditiously as possible and shall give its decision in writing and furnish a copy to each of the parties.

vii. The Tribunal shall have power to grant interlocutory injunctions to meet emergency needs of the parties.

\section{c) Jurisdiction}

No suit or other legal proceeding shall lie in any Civil Court in respect of any dispute, question or matter relating to any waqf, waqf property or other matter which is required by or under the Waqf Act to be determined by the Tribunal.

\section{A 'Circuit Waqf Tribunal'}

A problem which mutawallis or persons involved in a waqf dispute generally face is the necessity to travel long distances to come to the place where the Waqf Tribunal is based. This naturally involves expenditure of time and money. In case of mutawallis this money comes out of the Waqf fund itself.

It may be advisable, therefore, to constitute Circuit Tribunals, required to make regular periodic visits to the various areas within their jurisdiction according to a well advertised schedule. In a situation where a party needs to see the Tribunal urgently, it may visit it where it might be at that moment.

\section{ADR to Encourage Out-of-Court Settlement}

In the contemporary world, Alternative Dispute Resolution (ADR) has become very popular. ADR encourages parties to negotiate, mediate, arbitrate, or put their dispute for Expert Determination, etc., in order to settle their dispute without filing a law suit. Many of the waqf disputes are of petty nature which parties may settle without going to Tribunal. However, in serious matters involving ownership of waqf property, ADR mode of resolution might not be appropriate and a decision of the Tribunal would be necessary. If parties have already come to the Tribunal which considers that the dispute in its nature is referable to an appropriate 
ADR process, it may ask the parties to do so. If it results in compromise, then the Tribunal may issue a decree in terms of the settlement agreement, but where no compromise could be reached, the Tribunal may start its proceedings.

It is to be noted that where the judge of the Tribunal suggests to the parties to use one of the ADR processes, under no circumstances should he volunteer to act as Mediator, Arbitrator, etc., because if no compromise is reached, he could no more act as Judge of the Tribunal to avoid accusations of bias or partiality. It is presumed that during the course of mediation, etc., the judge must have formed a liking or disliking in favour of one or against the other party, and hence there is likelihood of bias to be reflected in his judgment.

In the Waqf Act there should be a provision stating clearly that the parties to a waqf dispute are encouraged to use any of the ADR processes to reach a settlement. If they wish to give their settlement agreement the status of a judicial decree for easy enforcement, they may register the agreement in the Tribunal, which, after examining the legality and propriety of the agreement, may issue the decree. As no appeal lies against the decision of a Tribunal, hence once it is registered, the settlement agreement would become final and binding on both parties.

\section{RECOVERY OF ENCROACHED WAQF PROPERTIES THROUGH ADMINISTRATIVE ACTION, NOT LITIGATION}

Encroachment on waqf properties is a very serious problem everywhere, targeting valuable properties which are located strategically in posh areas or commercial centres. Legal action is the only way to evict these encroachers. And this is the problem. In a country, there might be a very large number of such cases. It becomes a real problem to file so many law suits involving much expenditure, not only of money but time and energy. With their limited resources, it becomes an impossible proposition for waqf administrators to do so. Hence the need to find an alternative to litigation becomes a pressing need.

In Pakistan, the Waqf Ordinance 1979 of all the four Provinces provides that the Administrator of Waqf, who is a government appointed officer of fairly high rank, may summarily evict an encroacher. The evicted person may prefer an appeal to the Chief Administrator, whose 
decision shall be final. The evicted would be given reasonable opportunity of being heard and prove his case. This provision is the quickest mode of eviction I know of.

In India, the officer-in-charge of waqf administration in a State is not given the power to evict an encroacher by its own order. Section 54(4) of the Waqf Act 1995, enables an encroacher to file a suit in the Waqf Tribunal against the eviction order. The decision of the Tribunal is treated as final and no appeal lies against it.

Now, before action has started in the Tribunal or when proceedings before the Tribunal are in progress or where no application has been made to the Tribunal, the officer-in-charge of waqf may apply to the Sub-Divisional Magistrate for evicting the encroacher who by making order will evict the encroacher. An appeal against his order will lie to the Tribunal, and whose decision will over-ride any other order.

The problem with Pakistan model is the absence of any judicial review of an essentially administrative action, which is something so emphasized upon in Administrative Law. The Chief Administrator, to whom an appeal against the order passed by the Administrator goes, cannot be above accusation of bias. After all, the Administrator, who naturally would like to uphold the order of the officer working directly under him. So, if finality is attached to the order of the Chief Administrator, the requirement of judicial review is not fulfilled.

In India, on the other hand, the failure to provide the officer-in charge of waqf any power to issue eviction order adds one more step to be taken in this process that is, requesting the Sub-Divisional Magistrate to issue eviction order.

\section{Model Legal Provisions for Recovery}

Keeping the merits and demerits of these two models, it is possible to design a new model. Any country wishing to enact a Law relating to eviction of the encroachers may find the following suggested provisions useful:

i. The officer in-charge of waqf should be given power to issue eviction order on the encroacher of a waqf property. This may be specified in the Waqf Act itself. 
ii. Where the waqf officer is of the opinion that any person is in unauthorized occupation of a waqf property, he may issue a notice to such a person to show cause why he should not be evicted from this property.

a. If the waqf officer is not satisfied with the explanation given by the person, he may make an order of eviction.

b. If the person refuses or fails to comply with the orders, within the time specified in the order, the waqf officer shall evict that person, using such force as may be necessary.

iii. The order passed by the waqf officer shall be final if no appeal is made against it to the Tribunal or the Tribunal rejects it. The decision of the Tribunal shall be final.

iv. The order passed by the waqf officer shall not be questioned in any original suit and no injunction shall be granted by any court against it.

v. If the evicted encroacher reoccupies the same waqf property from which he has been evicted, he should be punished with imprisonment of a specified period and/or a fine of a specified amount.

vi. No court shall admit a case relating to the eviction of an encroacher from a waqf property, or issue an interlocutory injunction prohibiting such eviction, except as provided in the Waqf Act.

The involvement of Wqaf Tribunal in the above suggested model is necessary to make sure of the judicial review of administrative action without which the legality of action would remain doubtful. Any other model which places its reliance on legal action alone does not deserve consideration. 


\section{DEVELOPMENT OF WAQF PROPERTIES REVISITED}

Development of awqaf is the key to that treasure trove which our ancestors have left behind in the form of numerous awqaf which have now acquired economic potential beyond imagination, thanks to urbanization and appreciation in property valuation and rentals.

The average annual rate of return on investments made in developing waqf properties came to a minimum of 20-25\%. Which means whatever has been invested in developing awqaf may be recouped within 4-5 years. It is simply fantastic and worth serious attention.

In centuries past, there was probably not much of a need to boost waqf income through development to help the needy. Zakat, baitulmal and many generous persons were around to take care of the needy in society. Probably this is why we do not find in any description of mutawalli's duties any mention of 'development.' The emphasis which is found is on the proper upkeep of waqf property and ensuring collection and distribution of revenue among beneficiaries.

Development came into focus when, as a result of colonialism, the system of zakat and baitulmal were disrupted and the number of affluent Muslims was drastically reduced. And this situation is still continuing in a majority of countries. Enhancement of the income of existing awqaf has thus become a viable source to generate funds to meet the cost of social welfare schemes among Muslims.

What development of awqaf could achieve is astonishing. In India for example, 100 waqf properties developed at a total cost of Rs.124 million increased their income from a total of Rs.2.5 million to Rs.47.626 million, an increase of nearly $1900 \% .{ }^{13}$ Such phenomenal jumps in income are possible.

Assuming that there are at least one million waqf properties in the world, and majority of these are mosques, graveyards, dargahs, etc, which have either no economic potential or very little, followed by awqaf

$13 \quad$ Syed Khalid Rashid, "Islamic Financial Investments for the Development of Waqf properties: With Special Reference to India,” in Syed Khalid Rashid (ed), Protection, Maintenance and Development of Awqaf in India, (Institute of Objective Studies, New Delhi, 2005), at 61-63, cited in Social, Economic and Educational Status of the Muslim Community in India: A Report, (Prime Minister's High Level Committee, Govt. Of India, New Delhi, Nov. 2006) at 217-236. 
which are for specific objects, only about $10 \%$ are for general charitable purposes which are worth developing, so their enhanced income may be used for social welfare schemes without any legal hindrances.

The $10 \%$ of one million means 100,000 awqaf are worth developing. Now, against this number, if we count how many awqaf have been developed during the last 25 years, it comes to an insignificant figure. For instance, in India, during the last 36 years, only 75 major and 71 minor waqf properties were developed. ${ }^{14}$ The size of the properties is very small because the amount available for financing these projects is very small. The number of properties sponsored by the Awqaf Properties Investment Fund of IDB was 8 during 2002-03 and 7 during 2009 and in 2010 it became $5 .{ }^{15}$ World waqf foundation could have lent a helping hand, but the fact that it has not brought out its Annual Report since 2004 speaks for itself about its present 'inactive' status, for no apparent reason. ${ }^{16}$

There is no news worth mentioning relating to waqf development projects elsewhere except Malaysia where during the period 2008-2010 around 20 major and 70 minor projects have been completed. ${ }^{17}$ Even though the figures for the total number of waqf properties developed throughout the world are not available, yet on the basis of scanty information available, it is not difficult to see that the number is pretty small. At this rate a few centuries may be needed before completing the development of 100,000 properties and this calls for the adoption of a fresh strategy for this purpose.

\section{The Need for Change in Strategy}

The questions to be answered are: who will formulate the new strategy and what would it be?

$14 \quad$ The developments of these properties were financed by the Central Waqf Council, New Delhi with the help of ad hoc grants from the Govt. of India amounting to a meager sum of about US \$250,000 per year. http://centralWaqfcouncil.org/accessed on 28.5.2011.

15 IDB Annual Reports of 2002-3, 2009 and APIF Annual Report 2010.

16 Information collected from WWF office in June, 2011.

17 Information gathered from JAWHAR, Putrajaya, Malaysia, March, 2011. 
As an eminent international organization which is respected everywhere, IRTI and IDB may play an important role in designing a new strategy for waqf development. IDB enjoys the backing of not only the OIC countries but other countries also, both in the East and West. It may convince the stakeholders on the importance of development of awqaf for the socio-economic upliftment of the needy. If a country so likes, it may provide funds on the basis of long-term loan which may be paid off with the income of the developed awqaf.

Similarly, it may not be difficult for IDB to convince other Islamic banks and conventional banks with Islamic banking windows, the urgency and importance of providing funds for waqf development. They need to be told that it is also a safe investment.

A global target of 150 awqaf per year may be set, requiring financing in the range of US\$2-3 billion. Countries may be requested to jointly undertake with IDB feasibility studies of the economic potential of waqf properties so as to draw a priority list for purposes of undertaking development work.

There is a need of impressing upon the Islamic governments to revive the noble tradition of creating State awqaf. I am of the view that a waqf created by the head of a state (irsad) is a waqf in every sense, notwithstanding the fact that the ownership of the land being made waqf does not vest in the king personally but in bait al-mal. A little thought about the concept of ownership in Islam will clarify this point. According to the Qur'an, the ownership of everything on this earth and in the whole of universe belongs to Allah, who has given to man the trusteeship of these things. In common parlance, we call this trusteeship as 'ownership.' When a person or a king is being given this trusteeship, he becomes the 'owner' of the thing he holds as a trustee. Like a common man, when a king makes waqf of a thing he holds (or owns), a valid waqf comes into being, which has all the attributes which a waqf carries. Thus an irsad which is also known as al rizaq al ihbasiyah, is as valid a waqf as any other waqf, notwithstanding the fact that it is created by a king or head of a state of the land belonging to the state. ${ }^{18}$ The Waqf statutes in India,

$18 \quad$ See Muhammad Afifi (1991), Al-Awqaf wa'l Hayat al-Iqtisadiyah fi Misr fil-Asra al-Uthmani, (al- Hayat al-Nisriyah al-Ammah li'l Kitab) at 18, cited by Abdul Azim Islahi, A study of Muslim Economic Thought in the $11^{\text {th }} \mathrm{AH} / 17^{\text {th }} \mathrm{CE}$ Century,(Islamic Economics Research Centre, King Abdul Aziz University, Jeddah, Saudi Arabia, 1429 (2008), at 58. 
Pakistan and Bangladesh expressly include 'grants' made by anyone as waqf or to an existing waqf, within the definition of waqf. There are grants made by Hindu rajas of lands to be used as Muslim graveyards or in favour of dargahs.

During the three years 2008-2010, the Government of Malaysia spent RM258.607 million in developing 20 major awqaf consisting of 5 hotels, 2 orphanages, one shelter for deserted women, 3 commercial complexes, one school, and 5 infrastructural projects. The money spent on these projects is treated as grants, not loans. Another RM21.1 million ${ }^{19}$ was spent on the construction of 45 Waqf bazaars (consisting of 203 shops) in 10 different States. These bazaars have been built on Waqf lands adjacent to mosques. The 203 shops are only those completed up to $7^{\text {th }}$ Feb 2011. Some more shops are still under construction.

The importance and implications of Waqf development are generally not fully understood by the general public or even the governments. A Waqf Development Unit specially created in IDB may coordinate all the work connected with development, including public \& government enlightenment campaigns, talks and conferences, particularly among IDB member countries.

\section{Cash Waqf \& Waqf Certificates May Raise Funds \& Ensure Public Participation in Waqf Development}

In the present environment where Islamic banking has made interestfree investments possible, cash waqf has emerged as a dependable source for financing waqf development projects. Lump sum dedication of cash or small contributions from a large number of contributors to a common pool of waqf fund may easily become a development fund.

In Malaysia, for example, Maybank Islamic Bhd. (a Malaysian Bank Islamic) in collaboration with Yayasan Waqf Malaysia (Waqf Foundation of Malaysia, which is a government constituted body for looking after and undertaking waqf development in the country), launched in July, 2010 a deposit scheme that allows the Maybank account holders

$\overline{19} \quad$ These information have been personally collected from the office of JAWHAR (Dept. of Waqf, Haj \& Zakat, Govt. of Malaysia), March, 2011. 
to make cash waqf contributors to a common pool which is also used for the development of waqf properties. As Maybank is the country's biggest bank with 380 branches and assets exceeding RM40 billion, it is hoped that the scheme would be a big success.

In Singapore, the 175,000 Muslim employees were asked by the Islamic Religious Council of Singapore (MUIS) to allow deduction of certain amount from their salaries to raise a mosque building fund. The Central Provident Fund (CPF) collects the contributions as agent. During 2010 it collected S\$6 million. ${ }^{20}$

Through such schemes of small contributions, a common man on the street, who has no means to create a waqf of any substance, may derive satisfaction through his participation in such big waqf development projects. Allowing creation of awqaf or developing the existing ones through such pooling of small contributions is a sure way of reviving public interest in waqf.

All the stake holders in waqf development may popularize cash waqf \& waqf certificates. Government may grant tax exemption in countries where income tax is levied.

APIF may enter into collaboration with Islamic banks to jointly finance development of waqf properties, particularly in countries where Islamic banks do not exist, like India, Thailand, Sri Lanka, etc. Such collaboration will ensure availability of large amounts to fund to finance numerous waqf development schemes.

Early establishment of the Awqaf Development Bank under the auspises of the APIF will also greatly facilitate development of awqaf.

APIF may also utilize sukuk for raising funds needed for waqf development .The successful use of sukuk shows that very huge amounts may be raised through this Islamic financial instrument.

APIF needs to have a large staff to plan, supervise and execute a large number of developmental plans, in the range of at least 20-25 waqf properties per year. Anything less than this would be meaningless in the context of thousand of waqf properties waiting to be developed.

$20 \quad$ Information about Malaysia \& Singapore are personally collected by the author from respective offices. 


\section{Should Waqf Development be Made Statutorily Compulsory?}

My answer to this question is in the affirmative. It is advisable to make development compulsory for the person who may be managing a waqf property which is worth developing. If the waqf authority in a country finds that nothing has been done to develop the property even after giving notice to the person concerned, then the authority itself may assume this responsibility, or where it lacks financial resources to do so, it may delegate this work to a party which is so capable, usually an Islamic bank willing to take up this work as a business venture. Once the fund invested in the development has been fully recouped with some profit margin, the developed waqf property would be returned to the mutawalli.

To the best of my knowledge the (Indian) Waqf Act 1995 is the only waqf enactment which carries provisions regarding mandatory duty to develop a waqf property which is worth developing.

Section 32(4) of the Waqf Act 1995 provides that where the Waqf Board finds that a waqf offers a feasible potential for development, it may serve on the mutawalli a notice of at least 60 days to convey his decision about his willingness to execute such development.

In case of failure the Board may, with prior approval of the government, take over property, develop it and retain it along with its income till the amount invested in its development together with some profit is recouped. An amount as provided in the Act is paid to the mutawalli during all this period. After full recovery of invested amount the property should be handed back to the mutawalli.

It is a useful provision which may be adopted by any country after suitable adjustment to meet any local need.

The advantage of making development of waqf statutorily mandatory is to highlight the importance and need of development. In India no waqf board could ever take advantage of the provision because of their extremely poor financial condition. In addition, there is no Islamic banking or finance available in India. On a smaller scale, cooperative schemes which exist are not capable of financing big development projects.

A lesson worth learning is that in development of waqf what we need today is a proactive policy. Instead of waiting for an applicant to seek fund for the development, the concerned body dealing with waqf should itself identify the property and if necessary take it over to develop. 
Only then some result may be produced. Presently, a majority of mutawallis are not interested in development because of its demands on their time and energy. The secretary of the Central Waqf Council of India admits that-

"With some 300,000 waqf properties in India, the development of a 100 or so (awqaf) is not of much significance. However, the problem is...the lack of zeal on the part of the waqf institutions to undertake such projects."

\section{CONCLUSION}

The six issues raised in this paper are the ones which are of much contemporary relevance. Their degree of importance may differ from country to country, but all are equally important, in their own right. Survey of waqf properties to prepare a data-bank of awqaf in every country is such a necessity which needs no emphasis.

Full data of awqaf is a pre-requisite of effective management and this survey must be done in all the countries where it has yet to be undertaken.

Similarly, development of waqf properties needs adoption of a new strategy which takes into account the un-realistic and extremely slow rate at which development work is done today. A new realistic target is to be set that takes into account the large number of properties to be developed and the need for searching new sources of financing this initiative. Financing issue will be challenging, but so also is the problem.

The outright abolition of family awqaf without first undertaking a serious study of their alleged demerits and alleged negative effect on the economy and on an individual's ability of self-reliance, call for the reopening of this matter. IRTI/IDB may commission such a study on an international level to re-assess the viability and desirability of family awqaf in the light of direction contained in the Qur'an and ahadith to give to one's own kith and kin.

State control of waqf management is another issue which calls for a serious study. Right now in the midst of demands for democratisation, its relevance cannot be denied. People's participation in waqf administration is needed to bring transparency, accountability and efficiency. 
Bringing to an end the encroachment on waqf properties through administrative action but without ignoring the due process in case of those so evicted tackles a problem which is international in character. The available course of action through litigation is self defeating.

Similarly, litigation and its excessive cost have become a big drain on waqf income. The alternative in the form of waqf tribunals may bring a big improvement. So also the introduction of ADR processes (Negotiation, Mediation, Arbitration, etc.) in settling small time disputes in waqf matters.

Law and administrative rules, however, cannot cure all the ills. A clever and dishonest person may find one or other means to evade laws and rules. This is a problem which is seriously afflicting waqf administration in India. "The plundering hands of the non - God fearing mutawallis" is referred to in a recent report. ${ }^{21}$ It has now become a big problem everywhere and for which, unfortunately, there is no short cut solution. Such attributes like honesty, integrity and trustworthiness are attributes which take time to be infused. But these are needed in a waqf administrator, who is holding an office of trust. Everyone connected with waqf should therefore be reminded of the religious dimension of his responsibilities and duties. Moral and ethical education should be made part of continuing education and training of waqf administrators.

Efforts now being made and InshAllah measures to be taken shortly may make awqaf once again a major instrument for Muslim social welfare and progress.

Let me conclude by urging the Islamic Development Bank to accord an independent status to ' waqf' instead of treating it as an appendix to 'Islamic economics,' At the time when this was initially done, waqf studies were indeed not mature enough of being given an independent status. But now when the IDB itself has recognized the importance of waqf by establishing Awqaf Properties Investment Fund and World Waqf Foundation, and the attention now being given to waqf matters in various countries, waqf should no more be kept within the 'guardianship' of Islamic economics. It now qualifies to be given an independent status. A Waqf Studies Section need to be created within IRTI.

$21 \quad$ See, $9^{\text {th }}$ Report of Joint Parlimentary Committee on Waqf, (Rajya Sabha Secretariat, New Delhi, Oct. 2008). This report was submitted by the committee chaired by K. Rahman Khan, M.P and Deputy Chairman, Rajya Sabha . The Report is full of instances where human failures lie at the bottom of mismanagement of awqaf in India. 